\title{
Effectiveness Of Video Media Development Learning Skills Teaching On Micro Teaching Course
}

\author{
Eldarni $^{\mathrm{a}}$ \\ a Jurusan Kurikulum Dan Teknologi Pendidikan, Fakultas Ilmu Pendidikan, Universitas Negeri Padang \\ Corresponding e-mail: -
}

\begin{abstract}
The development of instructional video media with Adobe Premiere 6.0 application in Micro Teaching course on teaching skills is done as an effort to solve the problem of Micro Teaching course to overcome student difficulties in understanding teaching skill which must be mastered as a prospective educator. Development of this video media can help and facilitate students and lecturers in implementing learning and learning. This type of research is a research development known as Research and Development ( $\mathrm{R} \& \mathrm{D})$. This research uses 4-D development model. The development procedure in this research consists of 4 stages, namely the definition stage (define), the design stage (design), the development stage (development) and the dissemination stage (Disseminate). Product validity test is done by 3 validator that is 2 person validator media and 1 material validator. Trial of product conducted to 17 students of TP FIP UNP with aim to know the practicality of product developed. Affectivity test of video learning product Research instrument used is questionnaire, documentation, and assessment format.
\end{abstract}

Keywords: media video, micro teaching

\section{BACKGROUND}

The progress of a nation or state is determined by the quality of its human resources, the good human resources depend on education. The Indonesian nation will advance if the quality of education is also advanced. The quality of education in Indonesia must be improved and updated by keeping up with these developments. The need for us to think about how to educate the nation of Indonesia advanced but not just advanced but qualified and moral. At this time both elementary and secondary education and college education have been working together to advance education by altering innovative learning strategies.

Micro Teaching learning activities take place in the classroom with lecture, practice and simulation methods, but educators have not used the media in learning. As a qualified educator candidate, educators must be able to create a new, more enjoyable atmosphere. One of the efforts that can be done is to use instructional media that leads to the development of skills and knowledge that can foster student innovation by utilizing appropriate learning media, learners more freely to develop thinking power.

In the video media development courses that have been taught during lectures Curriculum and Technology Education in the learning process using video media that can be used as a medium in learning. So that based on the video students will be required to be able to produce a learning video. This video can later be used to support the learning process. Good at elementary school level up to college. This is closely related to the areas of Education Technology namely the design area, development area, management area, area of utilization and evaluation area. Well, referring to these areas of educational technology can help students in designing to produce video in learning. One of the competence areas is expertise Education Technology.

The development of video media in learning so rapidly, we can meet so many kinds of video media available. However, very few media videos are found to be associated with specific practices. For example is teaching skills. As we know in universities especially students in the field of 
education must master those skills before doing field practice. Especially in the Micro Teaching course.

Micro teaching learning activities, one of the problems that arise in the learning process is that students have difficulty in understanding the skills that must be owned. This learning is recommended using the media, because if this learning is done by presentation alone, then the Student will have difficulties in practicing the skills that must be owned or that will be learned as a prospective teacher.

One way to solve the problem is to use video media. The video will show clearly one by one of the skills that must be owned. Based on the above background, the authors want to develop a video that contains about the material in the Micro Teaching course so that the learning can help students in preparing themselves for field practice to be a good teacher. For that done research titled "Contribution

\section{Development Media Video Learning Skills Teaching at Micro Teaching Course".}

Based on the above description of the background, it can be formulated problems in the following aspects: 1) How developed video learning media is valid for use in learning?, 2) How is the learning video media developed practically used in learning ?,3) Is the learning video media developed Effective in learning?

The objectives to be achieved in this research are: 1) Produce teaching and learning media teaching skills in the form of a valid medium in accordance with the evaluation criteria and media eligibility. 2) Produce teaching learning media practical teaching skill in learning of Micro Teaching. 3) Produce learning video media about effective teaching skills for students.

\section{DISCUSSION}

\subsection{Development Method}

This type of research is a research development known as Research and Development ( $R$ \& D). Research and Development can be defined as a research method that aims to produce a specific product and test its effectiveness (Sugiyono 2013: 297).
Media development research Video learning using Adobe Premiere 6.0 application in the eyes of Micro Teaching course uses 4-D development model (Four D). According to S.Thigarajan et al (in Trianto, 2009: 109) "The four-D development model consists of four stages: Define, Design, Development, and Disseminate".

Technique of collecting data in this research is questionnaire of validity, questionnaire of practice and test. Instrument is aimed to know the validity of instructional video media, as well as to evaluate the feasibility of learning media using learning video for the purpose of improving students' ability in understanding the material in Micro Teaching course. Meanwhile, Step researchers in collecting data with the test method is to prepare the test questions, provide test questions, supervise the implementation of tests, collect test results, and examine and provide test scores.

Data collection was done by giving questionnaire to the respondent. After the data obtained, the next is data analysis techniques conducted is descriptive analysis of quantitative and qualitative to know the validity, practicality while to know the effectiveness of the product using quantitative descriptive analysis.

\section{$2.2 \quad$ Results}

Media validity test obtained from two lecturers of media namely lecturer of Curriculum and Technology of UNP Education namely Mr. Nofri Hendri, M.Pd and Mrs. Novrianti, M.Pd by giving suggestion and comment that are:

a)Video transition effect do not add rough

b)Collaborate with the scribe video at the beginning / end of the frame

c)Fix the Text at start-up with scribe videos and movie apps

d)Zoom effect on each skill

Validator I and Validator II provide input to the video media, then the media is revised based on suggestions and comments from the Validator or media expert, then perform the assessment by giving the assessment sheet in the form of a questionnaire. Media assessment results include the display and media elements that can be seen in the table below: 
Table 1: Expert Media Validation Rating Results

\begin{tabular}{|c|c|c|c|c|c|}
\hline \multirow{2}{*}{ No. } & \multirow{2}{*}{ Aspek } & \multirow{2}{*}{ Criteriaof Variabel } & \multirow{2}{*}{ Question Item } & \multicolumn{2}{|c|}{ Assessment } \\
\hline & & & & 1 & 2 \\
\hline \multirow[t]{19}{*}{1} & Media & A. Interface & 1 & 4 & 4 \\
\hline & & & 2 & 4 & 5 \\
\hline & & & 3 & 5 & 4 \\
\hline & & & 4 & 5 & 5 \\
\hline & & & 5 & 5 & 5 \\
\hline & & & 6 & 5 & 5 \\
\hline & & B. Media & 1 & 5 & 4 \\
\hline & & & 2 & 5 & 5 \\
\hline & & & 3 & 5 & 5 \\
\hline & & & 4 & 4 & 5 \\
\hline & & & 5 & 5 & 4 \\
\hline & & & 6 & 4 & 4 \\
\hline & & & 7 & 4 & 4 \\
\hline & & & 8 & 4 & 4 \\
\hline & & & 9 & 4 & 5 \\
\hline & & & 10 & 5 & 4 \\
\hline & & & 11 & 5 & 4 \\
\hline & & Total & & 78 & 76 \\
\hline & & Mean & & 4,58 & 4,47 \\
\hline
\end{tabular}

Media validity results assessed by Mr. Nofri Hendri, M. Pd as a validator I obtained an mean score of 4.58 with very good category. Overall score obtained from validator I on each indicator has been very good, that is by giving scores 4 and 5 . Scoring 4 in the aspect of display with good category found in indicators 1 and 2 there is the suitability of placement of images and video, on item 2 there is a match Technique of shooting or video. Whereas, in the aspect of the media elements, the language accuracy used by the presenter can be understood, the language used by the students can be understood, the accuracy of the selection of the type of writing in the video, the accuracy of the choice of writing size and the teaching style of the teacher. However, there are some comments or suggestions given on the assessment sheet by validator II so that it can be used as input and guidance that should be for the future, transition effects do not be rude.

Media validity results assessed by Mrs. Novrianti, M. Pd as validator II obtained mean score 4.47 with very good category. Namely by giving a score of 4 and 5. Scoring 4 on aspects of display with good category there is the accuracy of image and video placement and the accuracy of lighting techniques. Whereas, in the aspect of media element, there is the accuracy of the supporting capacity of narrative according to the material, the accuracy of the language used by the teacher can be understood, the accuracy of the language used by the students can be understood, the accuracy of the selection of writing type and the selection of writing size in the video, the clarity and quality of video and teaching style The teacher is good. However, there are some comments or suggestions given on the assessment sheet by validator II so that it can be used as input and guidance that should be for the future, fix the text on the initial screen with video scribe and movie application.

The result of material validity on video media obtained from lecturer of Micro Teaching Department of Curriculum and Education

Technology FIP UNP Drs. Zelhendri Zen, M.Pd suggestions and comments are:

a) Teachers stood too much in front

b) Teachers have not learned children because they talk too much

c) Development of cooperation (interaction between students is still lacking)

The material expert's validator provides input to the video media, then the media is revised based on suggestions and comments from the Validator or material expert, then performs the assessment by giving a questionnaire in the form of a questionnaire. Micro Teaching lecturers examine the material aspects of Media Video that have been designed. The results of the material assessment include conformity of concepts, material depth, material completeness and readability of the instructional video media made about teaching skills. This can be seen in the table below: 
Table 2. Experts Material Assessment Results

\begin{tabular}{cccc}
\hline Aspec & Criteria of Variabel & Indicator & \multicolumn{2}{c}{ Assessment } \\
\hline & The truth of Concept & 1 & 5 \\
& & 2 & 5 \\
Material & Material & 3 & 4 \\
& & 4 & 4 \\
& & 1 & 5 \\
& & 4 & 4 \\
& & 3 & 4 \\
& & 4 & 4 \\
& & 5 & 4 \\
& & 6 & 5 \\
& & 1 & 5 \\
\end{tabular}

The results of the validity of the material assessed by Mr. Zelhendri Zen, M. Pd as validator I obtained an mean score of 4.23 with very good category. Overall score obtained from validator I on each indicator is very good that is by giving scores 4 and 5. 1). In the Truth Concept variable there are 4 indicators. Validator I scores 5 and 4 . The scores of 5 are listed in indicators 1 and 2. According to the material validator in indicator 1 there is suitability between the competency standard of material clarity with the indicator, on indicator 2 there is clarity of learning indicator with $\mathrm{SK} / \mathrm{KD}$. A score of 4 is found in items 3 and 4 . On indicator 3 there is the suitability of the material with the purpose of learning, on indicator 4 there is the suitability of the material with indicators of achievement. 2). In the material depth variables there are 6 indicators, the validator I gave a score of 4 and 5 . The scoring of 5 is in the indicator 2. According to the material validator on the indicator of 2 materials can be presented comprehensively, While the indicator $1,3,4,5$ and 6 material validator Gives a value of 4 is the validator on the indicator 1 depth of material presented accordingly, on indicator 3 there is ease of understanding the material presented, in indicator 4 there is the suitability of the order of presentation of

learning materials, on indicator 5 there is a material mastery presented and on indicator 6 there is a suitability of the video with Material. 3). In the material completeness variables there is 1 indicator, the validator I gives a score of 5 on the indicator 1 is the completeness of the material presented. Validator material gives a value of 4 that is there is a complete material presented is good. 4). In the variable readability there are 2 indicators, the validator I gave a score of 5 The score of 5 is contained in items 1 and 2 . In item 1 there is readability of writing / text in the video is clearly legible. While in item 2 there is the use of language that can be understood.

Test of data practices in this stage which is the subject of trial is a student majoring in history of FIS

UNP who is following Micro Teaching course as many as 17 people. This activity was conducted to find out the student response to learning video media developed about teaching skill. Based on test results covering aspects of display, material and expediency. The results of feasibility can be seen from the assessment of each variable in table 3 . 
Table 3. Results of Trial Data on Students

\begin{tabular}{ccccccc}
\hline No. & Rated Aspect & Item & Mean & Score of variable & Max Skor & Presentation (\%) \\
\hline 1 & Interface & $1-10$ & 4,42 & 753 & 1000 & 75,3 \\
2 & Material & $11-14$ & 4,51 & 387 & 400 & 96,7 \\
3 & Expediency & $15-16$ & 4,73 & 161 & 200 & 80,5 \\
& & $\mathbf{1 6}$ & $\mathbf{4 , 5 5}$ & $\mathbf{1 0 1 7}$ & $\mathbf{1 6 0 0}$ & $\mathbf{8 4 , 1 6}$ \\
\hline
\end{tabular}

Based on the data of practicability by students of Curriculum and Technology Education UNP BP 2012 which is following Micro Teaching course above, it can be seen that the practicality judgment related to the display obtained a percentage of $80 \%$, thus the display value can be categorized as "good". Material acquired at $95 \%$ is categorized as "excellent". The practicality of obtaining $85.5 \%$ thus the value of benefit can be categorized "very good". The student's response to the media used is positive with the "excellent" criteria. Students feel interested and motivated to follow the learning process by using video media.

Activities undertaken by students after using Media Video learning that has been tested. This posttest activity to know the comparison of students before using Media Video and after using Media Table 4. Pretest Learning Outcomes And Post Test Students Department Curriculum and Educational Technology FIP UNP Courses Micro Teaching Video. Classes used Curriculum majors and Education Technology UNP who are following the course of Micro Teaching as many as 17 people on Wednesday $9.50 \mathrm{~s} / \mathrm{d} 12.20$.

Table 4. Pretest Learning Outcomes and Post Test Students Department Curriculum and Educational Technology FIP UNP Courses Micro Teaching

\begin{tabular}{|c|c|c|c|c|c|c|}
\hline No & Collage Student Name & Pre test & Post test & D & $(x) d=(d-M d)$ & $\left(X^{2}\right) d$ \\
\hline $\mathbf{I}$ & II & III & IV & $\mathbf{V}$ & VI & VII \\
\hline 1 & Aps & 72 & 94 & 22 & 0,24 & 0,0576 \\
\hline 2 & ES & 78 & 80 & 2 & 19,76 & 390,4576 \\
\hline 3 & IRN & 78 & 90 & 12 & 9,76 & 95,2576 \\
\hline 4 & $\mathrm{RF}$ & 64 & 88 & 24 & 2,24 & 5,0176 \\
\hline 5 & FD & 66 & 82 & 16 & 5,76 & 33,1776 \\
\hline 6 & $\mathrm{FN}$ & 68 & 90 & 22 & 0,24 & 0,0576 \\
\hline 7 & FR & 48 & 92 & 44 & 22,24 & 494,6176 \\
\hline 8 & SRN & 74 & 94 & 20 & 1,76 & 3,0976 \\
\hline 9 & MR & 50 & 64 & 14 & 7,76 & 60,2176 \\
\hline 10 & NIS & 68 & 92 & 24 & 2,24 & 5,0176 \\
\hline 11 & $\mathrm{RF}$ & 70 & 94 & 24 & 2,24 & 5,0176 \\
\hline 12 & SA & 70 & 96 & 26 & 4,24 & 17,9776 \\
\hline 13 & TR & 62 & 90 & 28 & 6,24 & 38,9376 \\
\hline 14 & US & 60 & 88 & 28 & 6,24 & 38,9376 \\
\hline 15 & FY & 58 & 70 & 12 & 9,76 & 95,2576 \\
\hline 16 & FH & 64 & 90 & 26 & 4,24 & 17,9776 \\
\hline \multirow[t]{2}{*}{17} & ZW & 68 & 94 & 26 & 4,24 & 17,9776 \\
\hline & Total & 1118 & 1488 & 370 & 0,08 & 1319,059 \\
\hline
\end{tabular}

Trial Pre test student in Micro Teaching course that amounted to 17 people with a result of 1118 . After doing the pre test is also done post test with the same class which amounted to 17 people with the results 1488. The results of student effectiveness tests on the Micro Teaching course obtained $t$ Counted 9.93 then searched $t$ table using table $t$ with
$\mathrm{df}=\mathrm{N}-1=17-1=16$ with $\alpha 0,05$ then $\mathrm{t}$ table is 2,12 , hence can be known $t$ value count bigger than $t$ table $(9,93>2.12)$.

Learning video media is designed in accordance with the needs of Curriculum and Technology Education. This product is not a main learning media in learning, but as a tool for educators and students 
in solving teaching problems, whether as media, complement or as an enrichment material. Through this video learning media is expected to overcome the problems in teaching Micro Teaching about teaching skills and can increase motivation in learning.

\section{CONCLUSION SUGGESTION}

\subsection{Conclusion}

Produce instructional videos and teaching skills that are valid and practical. Effectiveness of instructional video media on teaching skills of micro teaching courses.

\subsection{Suggestion}

The results of this study can be used by lecturers and students in micro teaching courses. Suggested to the department leadership to duplicate this video media for the pursuit of micro teaching courses.

\section{REFERENCES}

[1] Riana, Cepi. (2008). Media Pembelajaran. Bandung: CV Wacana Prima.

[2] Darmawan, Deni. (2010). Inovasi Pendidikan. Bandung: PT. Remaja Rosdakarya.

[3] Daryanto. (2010). Media Pembelajaran. Yogyakarta: Gava Media.

[3] Arikunto, Suharsimi (2012). Metodologi Penelitian Pendidikan: Kuantitatif dan Kualitatif. Jakarta: Raja Grafindo Persada.

[5] Sugiyono. (2012). Metode Penelitian Pendidikan: Pendekatan Kuantitatif dan Kualitatif. Bandung: Alfabeta. 